\title{
Reserch article: Studies on effect of micro nutrients application on morpho physiological traits in sweet corn
}

\author{
V.D. SALUNKE, A.G. MUNDHE, R.M. KOKATE AND R.V. BHANGARE
}

Article Chronicle: Received :

11.07.2017;

Accepted :

26.07.2017

KeY Words:

Effect of micronutrients, Application, Morpho physiological trait, Sweet corn
SUMMARY : A field experiment was conducted at Wheat and Maize Research Unit, VNMKV, Parbhani during Kharif 2016 to study the effect of micronutrients (Mg, $\mathrm{Zn}$ and $\mathrm{B})$ on morphological and physiological characters in sweet corn. The effect of 10 treatments viz., control $\left(\mathrm{T}_{1}\right), \operatorname{RDF}(120: 60: 50 \mathrm{~kg}$ NPK ha-1 $)\left(T_{2}\right), R D F+3$ Content, through soil $(\mathrm{Mg}+\mathrm{Zn}+\mathrm{B})(20 \mathrm{~kg}, 20 \mathrm{~kg}, 5 \mathrm{~kg}$ ha) $)$, respectively $\left(\mathrm{T}_{3}\right)$, $\mathrm{RDF}+\mathrm{Mg}(20 \mathrm{~kg}$ hà $)$ soil application at the time of sowing $\left(\mathrm{T}_{4}\right), \mathrm{RDF}+\mathrm{Zn}(20 \mathrm{~kg}$ hà $)$ soil application at the time of sowing $\left(\mathrm{T}_{5}\right), \mathrm{RDF}+\mathrm{B}\left(5 \mathrm{~kg} \mathrm{ha}^{1}\right)$ soil application at the time of sowing $\left(\mathrm{T}_{6}\right), \mathrm{RDF}+$ foliar application at 30 and $45 \mathrm{DAS}$ of $\mathrm{Mg}+\mathrm{Zn}+\mathrm{B} @ 1 \%$ (T), RDF+ foliar application of $\mathrm{Mg}$ at 30 and 45 DAS @ 1\% (T), RDF + foliar application of Zn at 35 and 45 DAS @ 1\% (T) and RDF + foliar application of B at 30 and 45 DAS @ 1\% ( $\mathrm{T}_{0}$ ) were evaluated for morpho-physiological traits.Results revealed that for chlorophyll content (SPAD) and leaf area at flowering and maturity, treatment $\mathrm{T}_{7}$ $\left(\mathrm{RDF}+\mathrm{Mg} \mathrm{SO}_{4}+\mathrm{Zn} \mathrm{SO}_{4}+\mathrm{B}\right.$ spraying @ $1 \%$ at 30 and $\left.45 \mathrm{DAS}\right)$ (64.87) found significantly superior over rest of the treatments. Further, similar treatment was also found significantly superior over rest of treatments, in respect of cob yield $\operatorname{plot}^{-1}(41.93 \mathrm{~kg})$ and cob yield ha-1 $(436.80 \mathrm{q})$ and at par with treatment $\mathrm{T}_{8}(\mathrm{RDF}+$ Foliar application of $\mathrm{Mg} @ 1 \%$ at 30 and $45 \mathrm{DAS})\left(36.42 \mathrm{~kg} \mathrm{plot}^{-1}\right.$ and $379.39 \mathrm{q}$ ha $^{-1}$ cob yield) and significantly superior over rest of the treatments.

How to cite this article : Salunke, V.D., Mundhe, A.G., Kokate, R.M. and Bhangare, R.V. (2017). Studies on effect of micro nutrients application on morpho physiological traits in sweet corn. Agric. Update, 12 (TECHSEAR4): 1024-1027; DOI: 10.15740/HAS/AU/12.TECHSEAR (4)2017/1024-1027.
Author for correspondence :

\section{A. G. MUNDHE}

Wheat and Maize Research Unit, (V.N.M.K.V.), PARBHANI (M.S.) INDIA

Email: anil.gm143@ gmail.com

See end of the article for authors' affiliations 